\title{
RISKS IN CHINA'S FINANCIAL SYSTEM
}

Zheng Michael Song

Wei Xiong

Working Paper 24230

http://www.nber.org/papers/w24230

\author{
NATIONAL BUREAU OF ECONOMIC RESEARCH \\ 1050 Massachusetts Avenue \\ Cambridge, MA 02138 \\ January 2018
}

The views expressed herein are those of the authors and do not necessarily reflect the views of the National Bureau of Economic Research.

NBER working papers are circulated for discussion and comment purposes. They have not been peer-reviewed or been subject to the review by the NBER Board of Directors that accompanies official NBER publications.

(C) 2018 by Zheng Michael Song and Wei Xiong. All rights reserved. Short sections of text, not to exceed two paragraphs, may be quoted without explicit permission provided that full credit, including (C) notice, is given to the source. 
Risks in China's Financial System

Zheng Michael Song and Wei Xiong

NBER Working Paper No. 24230

January 2018

JEL No. E00,E02,G00,G01

\begin{abstract}
$\underline{\text { ABSTRACT }}$
Motivated by growing concerns about the risks and instability of China's financial system, this article reviews several commonly perceived financial risks and discusses their roots in China's politico-economic institutions. We emphasize the need to evaluate these risks within China's unique economic and financial systems, in which the state and non-state sectors coexist and the financial system serves as a key tool of the government to fund its economic policies. Overall, we argue that: (1) financial crisis is unlikely to happen in the near future, and (2) the ultimate risk lies with China's economic growth, as a vicious circle of distortions in the financial system lowers the efficiency of capital allocation and economic growth and will eventually exacerbate financial risks in the long run.
\end{abstract}

Zheng Michael Song

Department of Economics

Chinese University of Hong Kong

Shatin, N.T., Hong Kong

zheng.michael.song@gmail.com

Wei Xiong

Princeton University

Department of Economics

Bendheim Center for Finance

Princeton, NJ 08450

and NBER

wxiong@princeton.edu 


\section{Introduction}

High leverage and soaring housing prices have caused wide concerns about the risks and instability of China's financial system. Figure 1 plots the ratio of the total outstanding debt (excluding central government debt) to GDP. By the end of 2015, the total debt stood above 20 trillion USD, with an annual growth rate of $20 \%$ since 2008 . The debt-GDP ratio, which was slightly above 1.2 in 2008 , skyrocketed to 2.1 in 2015 . The high leverage is associated with enormous appreciation in housing prices. In 2003-2013, housing prices in real terms grew at an annual real rate of $13.1 \%$ in the first-tier cities, $10.5 \%$ in the second-tier cities, and $7.9 \%$ in the third-tier cities (Fang, Gu, Xiong, and Zhou, 2015). Despite the recent strict measures to cool down the housing market, including a requirement of a $50 \%$ to $70 \%$ down payment on second homes and tight restrictions on third homes in big cities, housing prices continue to grow at a disturbingly fast pace. $^{2}$

Figure 1: Debt-to-GDP Ratio

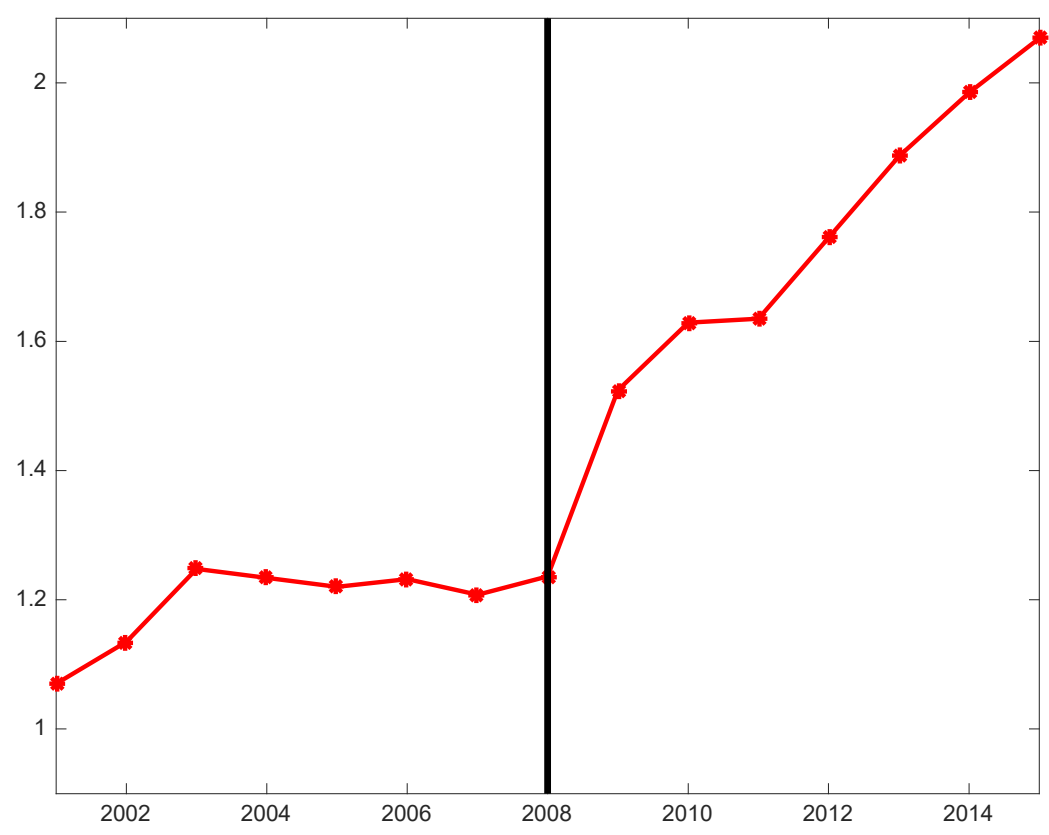

Note: The outstanding debt is backed out from "social financing statistics" provided by NBS, which measures lending from the financial sector to the non-financial sector

\footnotetext{
${ }^{2}$ Recent statistics from the National Bureau of Statistics (NBS) show that housing prices outgrew CPI by 12 percentage points in the 20 months from January 2016 to August 2017.
} 
(including bank loans, corporate bonds, and trust and entrusted loans but excluding equity finance).

There are also concerns about other sectors in the financial system. The 2015 stock market crash wiped out 3 trillion USD in share value. Despite the government's rescue plan to buy more than one trillion RMB worth of shares, the market has shown lackluster performance ever since. China accumulated almost 4 trillion USD in foreign reserves by 2014. Capital flight has become a serious issue since then. Foreign reserves of 1 trillion USD were lost in 2015 and 2016. The net capital outflow amounted to 1.5 trillion USD in these two years. A mild but sudden depreciation of the Chinese yuan occurred in August 2015. In 2016, the Chinese yuan depreciated by $10 \%$ against the USD and by $15 \%$ against a basket of currencies weighted by trade. Although the exchange rate has been stabilized recently, it came at a cost of much tighter capital controls.

To systematically assess these financial risks, it is necessary to anchor the assessment on China's unique economic structure that led to the current financial system. China started its economic transition in the late 1970s. A dual-track or gradualist approach has been adopted to tackle the fundamental issues inherited from the central planning regime, such as the soft budget constraint syndrome $a$ la Kornai $(1979,1980)$, that go hand in hand with a large but inefficient state sector. Although these problems have never been fully solved, they were greatly mitigated until 2008. Economic liberalization in the 1980 s led to a booming private sector. The state sector was consolidated by "Grasp the Large, Let Go of the Small" started in the mid-1990s. Local government budgets were tightened by the 1994 tax sharing reform and the 1995 Budget Law. A set of new rules and regulations were introduced to make commercial banks more independent after the 1997 Asian financial crisis. Consequently, investment went up, resource allocation improved and growth took off (see, e.g., Zhu (2012) and Zilibotti (2017)).

Unfortunately, the trend was reversed in the post-2008 period. China was hit hard by the 2008 financial crisis: GDP growth decreased from 15\% in 2007 to $10 \%$ in 2008 and then $8 \%$ in 2009 (see the dotted line in Figure 2). In response, the state launched a massive four trillion yuan stimulus plan in late 2008. While the stimulus boosted investment (see the solid line in Figure 2), it came at a cost of compromising some fiscal and financial institutional arrangements that were established to contain the problems such as soft budget constraints that originated from the dual- 
track reform (Bai, Hsieh and Song, 2016). As we will elaborate below, the economic stimulus worsened the soft budget constraint problem and reversed the flow of resources between the state and private sectors. Local government financing vehicles and state-owned enterprises (SOEs) increased their investment but crowded out more efficient private investment. While the aggregate investment did increase, misallocation worsened and growth slowed. Figure 2 shows that investment and growth used to comove closely before 2008. After 2008, they started to depart from each other. The investment rate increased to unprecedented levels above $45 \%$, while the growth rate fell to 7\%. Accordingly, aggregate TFP growth and returns to capital dropped dramatically (Bai and Zhang, 2015).

Figure 2: Investment and Growth

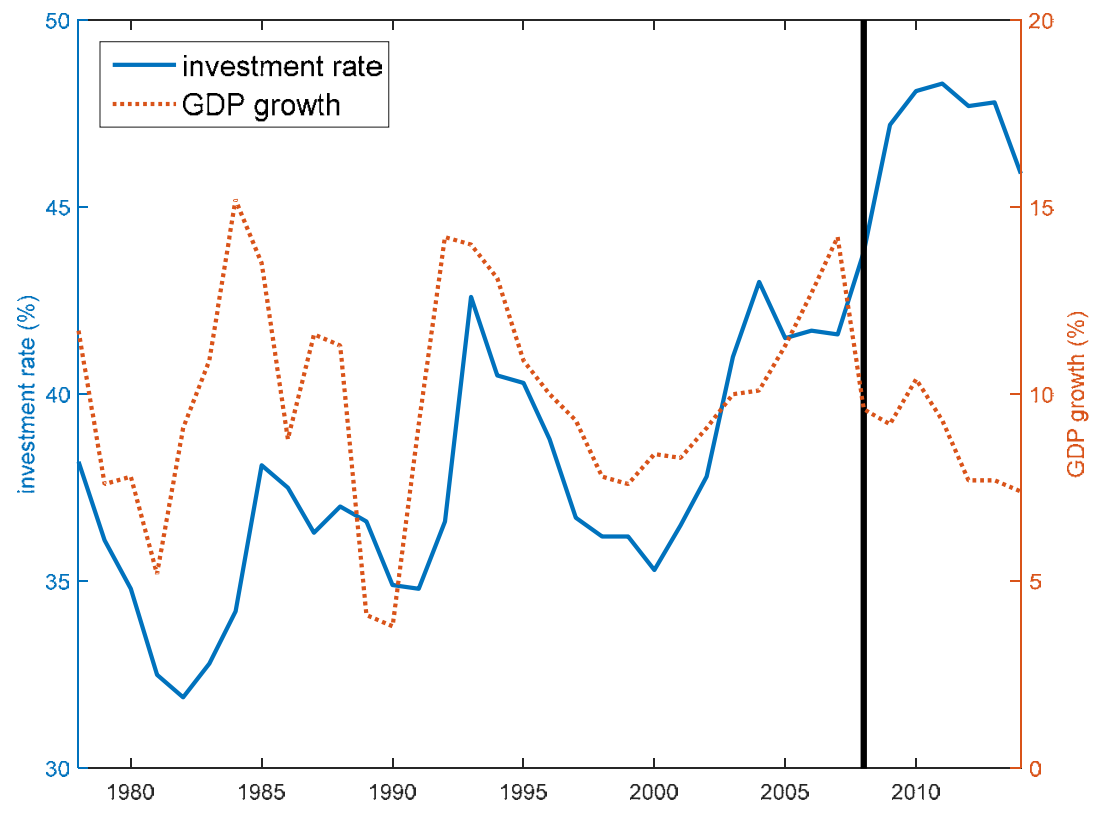

Data source: China Statistical Yearbook (various issues)

Such retreat reveals an important mission of China's financial system - it was largely developed to support the dual-track reform. State-owned commercial banks were reformed and guided to fund mostly SOEs. The state established the stock market in the early 1990s for two key purposes: (1) channeling private savings to SOEs; and (2) diversifying risks in the state-owned banking sector (see, e.g., Wong, 2006). The development of the bond market is no different. Zhou Xiaochuan, the governor of the People's Bank of China (PBC) since 2002, acknowledged that "administrative allocation of quotas (for bond issuance) was often used as a relief measure 
for financially distressed enterprises" (Zhou, 2006). The subsequent rapid development of the financial markets has never fixed this problem. In today's China, the state has loosened its direct controls of the financial system and financial supports have been extended to private businesses. Nevertheless, credit allocation favors SOEs and other connected private firms through explicit or implicit guarantees. Moreover, a softer budget constraint would intensify favoritism which, in turn, would entrench the soft budget constraint problem. This can be seen by the recent dramatic increase in the debt of local governments and listed firms, most of which are SOEs and connected private firms (Bai, Hsieh, and Song, 2016).

While the risks are concerning, we argue that they are unlikely to lead China to the same kind of financial crises experienced by western countries. First of all, the Chinese state controls a lot of resources through local governments, the banking system, SOEs, and the connected private firms. Although SOEs remain less efficient than private firms, the restructuring since the late 1990s has greatly improved the viability of the state sector, which was on the verge of collapse back then. Some SOEs even became highly profitable by establishing monopolistic positions in "strategic" industries. Second, Chinese households have high saving rates and low leverage levels. The economy runs a sizable trade surplus and does not have too much external debt. The financial sector is dominated by state-owned commercial banks. These provide flexibility for the state to steer through difficult times. Third, the rising leverage is mostly from state-owned banks to local governments, SOEs, and other connected private firms. This relationship makes it relatively easy for the state to resolve the coordination problem between creditors, as well as any externality in restructuring debt.

That said, we argue that the distortions in the dual-track system may cause a vicious circle that leads to more policy distortions, lowers economic growth, and lead to more financial risks in the long run. The recent firm data has shown signs of deteriorating allocation efficiency. Misallocation among Chinese industrial firms increased by 20\% (Bai, Hsieh, and Song, 2016) from 2008 to 2013. Preliminary estimates from Brandt, Wang, and Zhang (2017) also suggest a significant decline in TFP in most two-digit industrial sectors after 2007. The real estate boom across China also exacerbated the capital allocation inefficiency among industrial firms (Chen, Liu, Xiong, and Zhou, 2017). There is also a large policy risk. The financial system is becoming 
increasingly complex and cannot be handled with the traditional approach of "crossing the river by touching the stone." Policies and regulations can deliver unintended consequences, some of which may be entirely counter-productive, e.g., Hachem and Song (2016, 2017), Cai et al. (2017), Chen et al. (2017) and Chen, Petukhov, and Wang (2017). Such risks are further exacerbated by speculation about government invention (see e.g., Brunnermeier, Sockin, and Xiong (2017a, 2017b)).

The rest of the article is organized as follows. Section II reviews economic foundations for China's financial system. Section III will discuss the current economic and financial conditions in China. An analysis on China's financial risks will be conducted in Section IV.

\section{Economic Foundations}

The Chinese government developed the financial system with a mission to finance China's economic reform. This mission has so far dictated many aspects of China's financial system, such as its ownership structure, its development path, and the models it takes to finance different firms in the economy, which ultimately determine the risks and stability of the financial system itself. In this section, we briefly review China's economic reform and the roles played by the financial system.

\section{A. Dual-Track Liberalization}

The economic reform that the Chinese government started in early 1980s has led to spectacular economic growth during the past 35 years; the average annual growth rate has been nearly $10 \%$ and hundreds of millions of people have been lifted out of poverty. At the core of the reform was a dual-track approach that allows the co-existence of SOEs and private businesses. The success of the economic reform has proved several important advantages of this dual-track approach. First, it supports gradualism. As we will elaborate below, by continuing to support SOEs, the dual-track approach avoided a sudden collapse of the state sector, and the likely consequence of 
massive unemployment and social instability. ${ }^{3}$ For this reason, the dual-track approach is also referred to as a "reform without losers." "By minimizing the political resistance to private business, the dual-track approach has given birth to more than 20 million of private firms. In addition, the dual-track approach nurtured "crony capitalism with Chinese characteristics" (Bai, Hsieh, and Song, in progress). Many private firms are closely connected with local governments, which helps remove entry barriers, cuts red tape, and offers financial support. In fact, China's phenomenal growth largely has been driven by the growth of private businesses (see e.g., Song et al., 2011; Brandt et al., 2012).

Second, the boom of the private sector forced the state to improve the efficiency of SOEs and to tighten their soft budget constraints. The restructuring of the state sector was conducted under the slogan of "Grasp the Large, Let Go of the Small"- i.e., shutting down or privatizing small SOEs and corporatizing big SOEs. ${ }^{5}$ The transformation was successful to the extent that big SOEs improved their productivity relative to their private counterparts (Hsieh and Song, 2015). More important, fiscal decentralization was replaced with centralization by the 1994 tax sharing reform, the Budget Law and other policies and regulations. ${ }^{6}$ The central government is able to effectively control and allocate key resources in the economy, such as natural resources, public utilities, transportation, telecommunication, and finance through the SOEs (Lin, Cai, and Li, 1998). With its ability to mobilize these important resources, the Chinese government has an unparalleled capacity to implement its economic policies such as investment in large capital intensive infrastructure projects to upgrade roads, bridges, highways, airports, and ports throughout the country.

Nevertheless, the dual-track approach also comes with remarkable downsides. A key concern is that the protection of SOEs nurtures vested interests, which, in turn, blocks further reforms. Since 2008 , the size of the state sector has stabilized at a level around $30 \%$ of the industrial

\footnotetext{
${ }^{3}$ Wang (2016) develops a theoretical framework on the dynamic sustainability of China's politico-economic regime. ${ }^{4}$ Lau, Qian, and Roland (2000) establish the conditions under which dual-track price liberalization is Paretoimproving.

${ }^{5}$ The specific measures of corporatization include establishing corporate governance, introducing a profit-based evaluation system, rescinding administrative orders on daily operation, etc.

${ }^{6}$ This can be viewed as a turning point of decentralization or economic liberalization started in the 1980s (Huang, 2008).
} 
sector, and the TFP convergence between SOEs and private firms has also stopped, with the capital productivity of SOEs remaining at roughly half of that of private firms (Hsieh and Song, 2015). The state sector is even bigger in service industries, where misallocation is also significantly more severe (see Ge, Luo, Song and Yang, 2017).

In contrast to what one would have expected, the financial system served mainly to support the inefficient state sector rather than funding the booming private sector. The banking system was developed in the late 1970s and early 1980s by splitting the commercial banking businesses of the People's Bank of China into four state-owned commercial banks: Agricultural Bank of China, Bank of China, Construction Bank of China and Industrial and Commercial Bank of China. These state banks provided disproportional amounts of bank loans to support ailing SOEs and suffered enormous capital losses in the 1990s and the early 2000 s. ${ }^{7}$ With the banking system substantially limited by its bad loans, the stock market was created in the early 1990s to provide another funding source for the SOEs, as well as a mechanism to reform their government, e.g., Allen and Shen (2012) and Allen, Qian, and Gu (2017). The two stock exchanges in Shanghai and Shenzhen primarily listed SOEs in the early years; it only started to list private firms recently. The two bond markets, one interbank market established in 1996 and the other exchange market established in 2007, also favor bonds issued by local governments and SOEs (see e.g., Borst and Lardy, 2015). As we will elaborate below, the special mission of the financial system to support SOEs has had profound impacts on both efficiency and risks of the financial system. In particular, it made the financial system heavily exposed to the problems of SOEs.

\section{B. Soft Budget Constraint}

Soft budget constraint is a term originated from Kornai's study of centrally planned and transition economies. It can arise in many circumstances due to the lack of commitment not to support the BC-organization (i.e., the organization has a budget constraint) by the S-organization (i.e., the organization ready to cover deficits of the BC-organization). ${ }^{8}$ In the context of China,

\footnotetext{
${ }^{7}$ See, e.g., Allen, Qian, Zhang, and Zhao (2012) and Walter and Howie (2012). In the 1980s and 1990s, nonperforming loans were typically absorbed by money creation that led to chronic high inflation (Brandt and Zhu, 2000).

${ }^{8}$ See e.g., Dewatripont and Maskin (1995) and Kornai, Maskin, and Roland (2003).
} 
SOEs enjoy a soft budget constraint as the government lacks the commitment to liquidate losing SOEs. Soft budget constraint per se is a powerful explanation for the low efficiency of the state sector. The soft budget constraint, provided by the government through explicit and implicit subsidies, is also a cornerstone for the asymmetry in access to financial resources between SOEs and private firms, which has been vital to the survival of SOEs.

The favoritism for SOEs is ubiquitous in China's financial system. For instance, SOEs can borrow at regulated interest rates and go public with priority, while most private firms have to rely on internal financing or borrow from informal channels at much higher interest rates (Allen, Qian, and Qian, 2005). The responsibility of the state banks to support the soft budget constraint of the SOEs has also been a key source of bad loans for state banks in the 1990s and the early 2000s. ${ }^{9}$ Consequently, there is a large and persistent gap of returns to capital between SOEs and private firms. Capital allocation is severely distorted (Hsieh and Klenow, 2009; Hsieh and Song, 2015; Song and $\mathrm{Wu}, 2015)$.

All the major commercial banks are state-owned and enjoy a soft budget constraint themselves. Their profits are supported by the spread between the benchmark bank deposit rates and lending rates, which are set by the People's Bank of China. ${ }^{10}$ This spread has remained around $3 \%$ in the past 20 years. When this spread was insufficient to cover the bad loans of these banks in the 1990s and early 2000s, the government twice recapitalized them and eventually listed all of them in the stock markets both inside China on the Shanghai Stock Exchange and outside on the Hong Kong Stock Exchange.

Local governments at all levels of the government hierarchy also enjoy a soft budget constraint from the central government. Fiscal decentralization in the 1980s allowed local officials to keep fiscal surpluses, which could be used to support local projects. Local fiscal capacity has been greatly expanded by land revenue since the 1990s. As will be discussed in Section III, the

\footnotetext{
${ }^{9}$ See Allen and Qian (2014) for the mandate of the stock market to fund SOEs as a reason for the lack of efficiency of China's stock market.

${ }^{10}$ See Section III for China's interest rate liberalization.
} 
"financial deregulation" after 2008 further relaxed local governments' budget constraint, granting more flexibility for local officials to influence credit allocation.

A direct implication of the soft budget constraint is that SOEs, state banks, and local governments are not as price sensitive as one would expect from profit-maximizing agents. For example, after the crisis-induced economic stimulus program ended in 2010, despite that the central government explicitly instructed local governments to scale down many of their projects and banks to stop funding those projects, local governments continued to scale up rather than down, and managed to obtain funding from the shadow banking system at substantially higher costs (Chen, He, and Liu, 2017). When a substantial fraction of the participants are not particularly sensitive to the costs of funding, it is difficult for asset prices determined by the typical market equilibrium to be efficiently anchored on the asset fundamentals. Thus, the lack of price sensitivity of these important institutions has been a key obstacle for China to develop a market-driven financial system. This is also a key reason for the PBC's current use of a quantitybased monetary policy framework that directly targets money supply (Sun, 2015), rather than a seemingly more convenient price-based framework that anchors on interest rates like the one used by the U.S. Federal Reserve Board.

Another implication of the soft budget constraint is implicit government guarantees. Specifically, even when SOEs, state banks, and local governments suffer large financial losses, their creditors anticipate the government will bail them out. As a result, creditors continue to offer them credit at substantially lower costs relative to private firms with similar financial status. This in turn encourages them to further build up, rather than scale down, financial leverage. This kind of riskseeking problem is a standard agency problem, caused by the implicit government guarantee, and is a key for understanding risks in China's financial system. Zhu (2016) provides an extensive account of how government guarantees might have contributed to excessive speculation and price bubbles in China.

\section{China's Current Economic and Financial Conditions}


In this section, we will investigate the current economic and financial conditions in China's household, corporate, and government sectors. We will also review recent developments in the financial system.

\section{A. Households and Firms}

China saves about half of its GDP (the solid line in Figure 3). The high aggregate saving rate comes from high savings by both households and firms. China's urban household survey, which biases saving rates downward by underrepresenting rich households, shows an average saving rate of $30 \%$. The national data adjusted by NBS suggests the household sector saves more than $40 \%$ of its earnings. There is a long list of factors that may contribute to the extraordinarily high household saving rate. ${ }^{11}$ All the factors are associated with some China-specific institutional features, suggesting that high household savings are likely to persist in the near future.

Figure 3: Saving and Investment

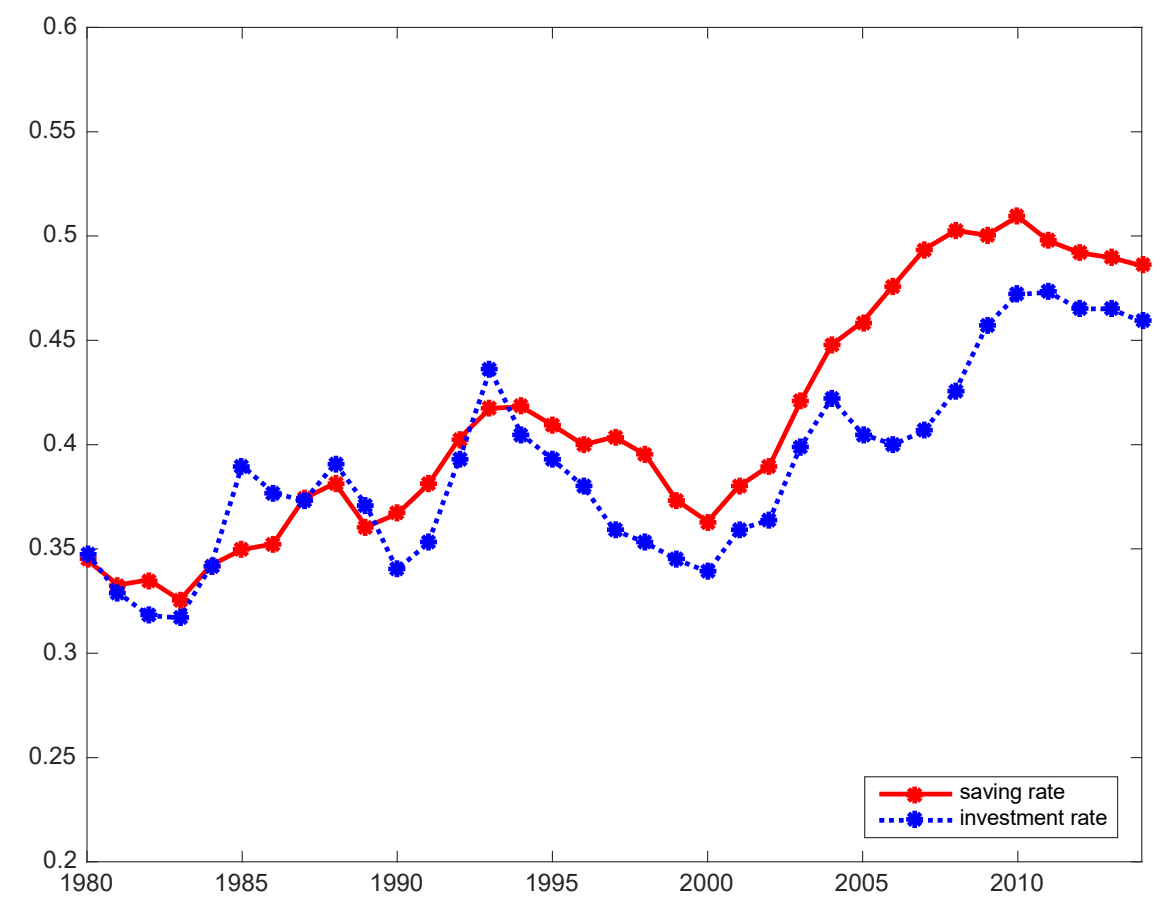

Data source: China Statistical Yearbook

\footnotetext{
${ }^{11}$ See Yang (2012) for a literature review. See also Wei and Zhang (2011), Chen and Chen (2016), Choukhmane, Coeurdacier, and Jin (2016), and Copper and Zhu (2017) for more recent work.
} 
The housing price boom greatly increased the net worth of Chinese households. Despite the fastgrowing mortgage, balance sheet of Chinese households remains solid. Only $30 \%$ of bank loans are made to households (mostly mortgage loans). The required down payment is high: $20 \%$ for first homes and 30\% for second homes. To curb the recent housing price boom, the required down payment was raised at some point to $50 \%$ or higher in some big cities. Even a significant housing price adjustment would be unlikely to trigger a mortgage crisis of the scale seen in the Great Recession.

Chinese firms also save a lot. The corporate sector accounts for about half of the nongovernment savings (Yang, Zhang, and Zhou, 2011). The literature is relatively thin on China's high corporate saving rate. Yet, it has been widely acknowledged that this is caused by firms' precautionary motives (see, e.g., Li, 2001; Gordon and Li, 2003). Due to the nature of the dualtrack reform discussed above, the financial system - including banks, the stock market, and the bond market - favors SOEs. As a result, most private businesses were excluded from the formal credit channels and private investment was primarily financed by firms' own savings (Allen, Qian, and Qian, 2005). In turn, higher returns to investment in the private sector-the flip side of the higher financing costs - encourage private firms to save more. Again, this is unlikely to change in the near future.

Despite the financial frictions and other barriers, the private sector has been flourishing over the past two decades. It now accounts for $80 \%$ of China's urban employment and continues to be the main growth engine. The inefficient state sector used to be a big burden that could possibly drag China into a crisis. While the reform of the state sector is far from complete, the surviving SOEs have greatly improved their vitality. In contrast to their moribund status in the 1990s, today's SOEs do not pose an imminent threat to China's economic and financial stability. In fact, some of the SOEs have even managed to establish monopolistic positions in various upstream industries, such as energy, transportation, telecommunications, and finance, under the protection of industry regulations (see e.g., Li, Liu, and Wang, 2014). The main concern is now more on the relatively low efficiency of the state sector and its long-run implications. 
In summary, China's domestic savings are more than enough to finance its investment, a blessing for a fast-growing economy. Figure 3 shows that the aggregate saving rate has been above the investment rate since the mid 1990s - a mirror image of China's trade surplus (Song, Storesletten, and Zilibotti, 2017). The investment boom in the post-2008 period has reduced but has not yet completely removed the surplus. There is no significant external debt. A Greece-like crisis is not likely to happen.

\section{B. Local Governments}

Local governments have played an important role in China's economic development as well as financial risks related to rising real estate prices and rising leverage across China. The central government have formed a tournament between local officials to encourage development in their local economies, e.g., Zhou (2002, 2007) and Li \& Zhou (2005). To outperform others, local officials need to build up local infrastructures (such as roads and highways), which in turn help to attract businesses and investments. Competition between regions also drives local officials to provide resources, such as startup funds, tax subsidies, and land subsidies, to facilitate local business development and bail out nonperforming SOEs. This is referred to as "decentralized authoritarianism” (Xu, 2011) or China-style crony capitalism (Bai, Hsieh, and Song, in progress).

The Budget Law enacted in 1994 prohibited local governments from running budgetary deficits. External financing was not allowed either. ${ }^{12}$ This has been widely viewed as a critical step in confining the soft budget constraint problem between local governments and their favored businesses. Instead, since the late 1990s, local governments greatly expanded their fiscal capacity by relying on non-budgetary funding sources such as land revenue. The Chinese constitution states that urban land is owned by the state. In practice, land is administered by local governments. Revenue from sales of land use rights (land revenue henceforth) has accounted for about one-third of local government revenue (the sum of local fiscal revenue and land revenue) since the early 2000 s.

\footnotetext{
12 The central government has modest fiscal deficits, with the deficit to GDP ratio of a mere two to three percent.
} 
Tying local government budget to land revenue is a novel design mechanism. Given the initial condition of underdevelopment across Chinese cities, local tax revenue was far from covering the need for funding large capital intensive infrastructure projects and other local business developments. The great uncertainty would also discourage banks from funding such projects, even if local governments were allowed to directly raise debt financing. On the other hand, like equity prices, the land prices that buyers pay are determined not only by the current business conditions in a city but also their expected future conditions. Conditional on local governments using land revenue to improve local infrastructure and business environments, land prices can be substantially higher than what is justified by current business conditions, just like the oftenobserved high share prices of new technology firms even when they have no earnings yet. The need for local governments to regularly sell land to the public also serves as a device to discipline them to carry out their pledged infrastructure projects. This arrangement is similar to staged venture capital financing for new firms.

This budgetary arrangement gives local governments the necessary resources and incentives to invest in infrastructure projects and support local businesses, which had greatly contributed to the rapid urban and business developments across Chinese cities. The net effect of this budgetary reform on the soft budget constraint is ambiguous, as local governments also have more resources to bail out failed businesses. ${ }^{13}$

The heavy budgetary reliance of local governments on land revenue also has profound implications for the real estate sector. As local governments are monopolistic land suppliers, the estimate of Wu, Gyourko, and Deng (2012) suggests that much of the increase in housing prices occurred in land values. Concerns about the financial health of local governments also prompted the central government to frequently intervene in real estate markets, using measures such as mortgage policies to home buyers and credit policies to real estate developers, to manage potential cycles in the real estate prices, e.g. Fang, Gu, Xiong, and Zhou (2015). As we will

\footnotetext{
${ }^{13}$ New land sales improve factor mobility and, hence, increase the opportunity cost of bailouts, through the lens of Qian and Roland (1998). In addition, land prices (especially residential and commercial land prices) are essentially determined by market forces, particularly, local productivity. Diverting too much resources to inefficient businesses would eventually affect land prices and revenue. These are the disciplining mechanisms that harden local governments' budget constraints.
} 
discuss later, these interventions in turn encourage real estate speculation of households and firms to acquire investment homes and land (see e.g., Chen, Liu, Xiong, and Zhou (2017)).

The 2008 stimulus plan compromised the borrowing constraint on local governments. Bai, Hsieh and Song (2016) demonstrate that most of the stimulus was financed by local governments through bank loans, as local governments could not have sold so much land to cover the stimulus. To facilitate local financing, the central government, for the first time since the early 1980 s, relaxed the financial controls on local governments. A prominent regulatory change made by CBRC turned out to be a key step (Document No. 92, CBRC, March 18, 2009). Specifically, local governments were encouraged to set up local government financing vehicles (LGFVs) to borrow from banks and financial institutions. This circumvents the Budget Law that prohibits local government from borrowing. Auxiliary regulatory changes were also made by various units in the central government (including the Ministry of Finance) to endorse LGFVs. Consequently, about 1,800 LGFVs issued bonds by 2015, while less than 100 did so before 2008. Local government debt is accumulating disturbingly fast even by the official statistics: The outstanding local government debt increased from less than 5 trillion yuan in 2008 to 23 trillion yuan in 2015. Bai, Hsieh, and Song (2016) argue that a lot of debt borrowed by LGFVs is not officially classified as local government debt. Their estimates suggest that the outstanding debt of LGFVs could be 46 trillion yuan in 2015, which is twice as much as the official size of local government debt and about two-thirds of GDP in that year.

Nevertheless, it would be a farstretch to conclude that local governments are becoming illiquid or insolvent. With annual fiscal revenues of 8 trillion yuan and annual land revenues of 3 trillion yuan, local governments have sufficient cash flow to pay the interest on their debt. Moreover, LGFVs' assets actually outgrew their liability. For the 1,800 LGFVs studied by Bai et al (2016), their total assets amount to 70 trillion yuan- $50 \%$ more than their liability. Much of the assets are land reserves. In other words, local governments are unlikely to be illiquid or insolvent in the near future unless China experiences a dramatic land price adjustment.

\section{Financial Institutions}


China has a bank-based financial system. Bond and equity financing only account for about onefifth of the total credit to non-financial institutions. Unlike the non-financial sector, the financial sector is predominated by state-owned financial institutions. Most banks are state-owned. The Big Four alone contribute to more than $40 \%$ of total bank deposits. The main business of China's commercial banks is taking deposits and making loans. Before 2015, bank profits were guaranteed by interest-rate regulation that imposed a floor for the loan rate and a ceiling for the deposit rate, both around the benchmark loan rate and deposit rate published by the PBC. These benchmark rates usually leave a spread around 3 percentage points, which is the main source of bank revenue. In 2015, the floor and cap were removed as a key to liberalizing interest rates. Nevertheless, the PBC continues to publish benchmark deposit and loan rates, and banks continue to closely follow them and profit from the spread.

In the early stage of the economic reform, soft budget constraint was a major concern for the banking sector. The moribund state sector in the late 1990s led to a crumbling banking sector, where the ratio of non-performing loans reached a record high of $30 \%$ in the early 2000 s. Analogous to the corporatization of big SOEs, state-owned banks have experienced similar transformations that have made them more independent and profit-driven. ${ }^{14}$ This process led to a much more competitive banking sector, which promoted financial innovations and eventually fostered shadow banking. The Big Four commercial banks were established in the late 1970s and early 1980s, as spinoffs of the commercial part of the PBC. The Big Four enjoyed a disproportional share of the depositor pool. In contrast, the smaller banks, which are relatively new, lack household deposits and need to rely on interbank funding from the Big Four.

The competition for deposits among banks led to the rise of a wealth management product (WMP henceforth), which is a saving instrument that is not constrained by the deposit rate ceiling. In the mid-2000s, banks started to issue WMPs with higher returns. ${ }^{15}$ The tightening of the loan-to-deposit cap in the late 2000s further gave rise to non-guaranteed WMPs, which can move loans and deposits off balance sheets. This led to rich shadow banking activities (Hachem

\footnotetext{
14 The Law of the PBC and the Law of Commercial Bank were enacted in 1995 to guide and regulate banks' daily operations. The reform was further solidified by the establishment of the CBRC in 2003, which took over banking supervision from the PBC, and the public listing of all the major commercial banks in the 2000s.

${ }^{15}$ Acharya, Qian, and Yang (2016) provide evidence for the role of banking competition.
} 
and Song, 2016). ${ }^{16}$ The dashed line in Figure 4 plots WMP as percentage of GDP, which increases from $2 \%$ in 2007 to $34 \%$ in 2015 .

Figure 4: The Size of Wealth Management Products

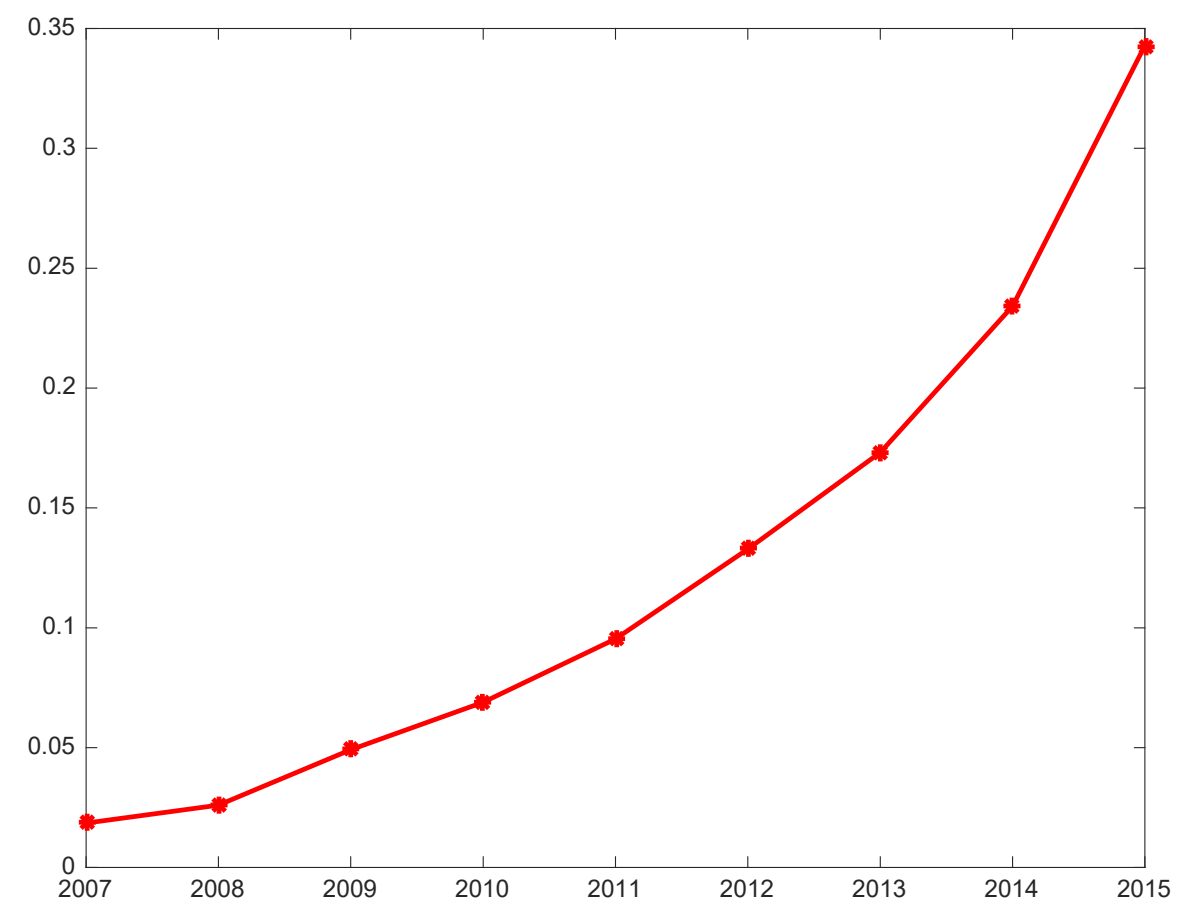

Note: The figure plots total WMP balances as percent of GDP. Data source: China's Banking Wealth Management Market Annual Report (various issues)

On the asset side, the bank-trust cooperation is a first-generation off-balance-sheet channel that provides credit to firms that would have difficulty obtaining external financing otherwise. More WMPs were invested in municipal corporate bonds after 2011. As we discussed before, local government financing vehicles (LGFVs) continued to grow after the stimulus program ended in 2010 and needed to pay back their bank loans. Chen, He, and Liu (2017) argue that the rollover pressure precipitated the rapid growth of the shadow banking system, through which LGFVs were able to roll over their debt. ${ }^{17}$ See Hachem (2017) for more detailed reviews on the growing literature on China's shadow banking and Zhu (2017) for an analysis on its welfare implications.

\footnotetext{
${ }^{16}$ See also Guofeng Sun's article on VoxChina regarding the rise of China's shadow banking from a regulator's perspective: http://voxchina.org/show-3-45.html.

${ }^{17}$ Specifically, they find that providences with abnormally greater bank loan growth in 2009 experienced more municipal corporate bonds issuance (which was mostly through the shadow system) in 2012-2015.
} 
Despite the recent rapid development of shadow banking, its overall size remains modest, with the total WMP balance being merely $18 \%$ of total bank deposits by the end of $2015,{ }^{18}$ partly because the central government has tightened regulations by incorporating shadow banking activities into the PBC's macroprudential policy framework and thus imposing required capital on banks for such activities. The rise of shadow banking has nevertheless presented a great challenge to China's monetary policy, which adopts a quantity-based framework with an intermediate policy target on money growth. ${ }^{19}$ Concerned by the difficulty in fully accounting for banks' on- and off-balance sheet activities, the PBC has been pushing strongly for interest-rate liberalization, which is the necessary foundation for it to ultimately adopt a price-based monetary policy framework as an automatic stabilizer. To expose banks to more market competition, the $\mathrm{PBC}$ has been actively promoting the bond market, which has experienced rapid growth in recent years. The bond market now trades bonds issued by the central and local governments, as well as SOEs and publicly listed firms. The outstanding quantity of bonds has recently reached over $30 \%$ of bank loans. Equity financing accounts for a much smaller fraction of the total credit. As will be discussed in the following section, there have been very few defaults and delistings in China's bond and stock markets - a natural consequence of the above features associated with the dual-track reform. Interest-rate liberalization in such a financial system may cause more capital to flow to the state sector or the shadow banking and, hence, aggravate welfare losses, e.g., Liu, Wang and $\mathrm{Xu}$ (2017) and Wang et al. (2017).

\section{Financial Risks}

\section{$\underline{\text { A. Debt Crisis Risk }}$}

\footnotetext{
${ }^{18}$ Entrusted loans are also an important part of China's shadow banking. See Allen, Qian, Tu and Yu (2016), Chen, Ren and Zha (2016), Du, Li and Wang (2016) for entrusted loans made by listed firms.

${ }^{19} \mathrm{Li}$ and Liu (2017) provides evidence on China's quantity-based money policy. Sun and Jia (2015), Chen, Ren and Zha (2016) and Hachem and Song (2017) show how shadow banking can create money uncounted and credit boom unexpected by the financial system.
} 
As discussed earlier, the issue of quickly rising financial leverage across China has arisen in recent years. In particular, a substantial fraction of the sharply increased debt was channeled through shadow banking. The joint occurrence of rapid housing price appreciation and quickly rising debt levels has alerted many commentators to the possibility of a debt crisis in China, e.g., Chen (2015) and Maliszewski et al. (2016). In particular, many are worried that China might follow in the footsteps of the U.S., which experienced a severe financial crisis initially triggered by the reversal of a dramatic housing boom in the mid-2000s. The U.S. housing boom was largely financed by a dramatic credit expansion across the country to households and financial firms, and in particular, credit expansion through the shadow banking system to subprime households (see e.g., Mian and Sufi, 2009).

We believe that a Western-style debt crisis is unlikely to occur in China in the short run for the following reasons. First, China has a large pool of domestic savings. Second, China has a low level of external debt. Most of the debt in China is issued not only domestically but also even more conveniently from state-owned banks to state-owned firms. In fact, such asymmetry has been further strengthened in the post-2009 period for reasons discussed above. The analysis by Chivakul and Lam (2015), for instance, indicates that among listed firms, the SOEs' leverage grew much faster than private firms' after 2009. Even though some of the debt might have been issued informally through the shadow banking system, this debt structure nevertheless makes the debt problem manageable by the government. Third, the Chinese government has accumulated rich experiences in resolving bad loans in the banking system. In the 1990s and early 2000s, the central government has adopted a wide range of tactics to clean up the bad loans piled up in the state banks. ${ }^{20}$

A debt crisis in the Western world occurs usually when the borrower and the lenders cannot agree to a mutually acceptable scheme to avoid costly bankruptcy due to all sorts of coordination and hold-up problems. For example, with a pool of lenders, the lenders would often run into a difficult coordination problem among themselves when the borrower faces financial difficulty. That is, a lender may choose to abandon a borrower preemptively even when the borrower's

\footnotetext{
${ }^{20}$ For example, four large asset management companies were created, one for each of the Big Four, to absorb their non-performing loans. See Walter and Howie (2012) for a detailed account of these tactics.
} 
financial status is just starting to deteriorate but is still sound. This happens when the lender is worried about holding a sinking ship when other lenders choose to dump the borrower, e.g., Morris and Shin (2004) and He and Xiong (2012). This kind of coordination problem underlies the well-known bank-run problem, which troubles the Western banking system at its core, e.g., Diamond and Dybvig (1983). With the presence of an actively engaged central government in China's financial system, this kind of coordination problem is less likely to emerge as the central government would step in to coordinate the lenders when needed.

Another important friction in debt crises is the inherent conflict of interest between the borrower and the lenders. As a typical debt contract gives the borrower a limited downside but all the upside, he has the natural incentive to seek risk. To the contrary, the lenders are strongly averse to risk, as they have only a limited upside from collecting the promised payments but plenty of downside in losing their initial loans. This conflict would again motivate the lenders to take on inefficient decisions to minimize risk, such as premature liquidation of a firm to preserve their stake in the firm, or constraining a troubled firm from taking on risky but promising investments (called debt overhang by Myers (1977)). State ownership in both lender and borrower sides of the debt makes it possible to resolve this kind of hold-up problem by converting debt into equity, as frequently occurred in China. ${ }^{21}$

For these reasons, we believe that rising leverage per se would not lead China to a Western-style debt crisis. Having said that, it is nevertheless important to recognize other problems associated with the rising leverage, in particular the efficiency of credit allocation during this credit boom. Chen et al. (2016) show that during China's economic stimulus, bank credit was allocated disproportionally to financing investment in real estate and heavy industries, which reflected the government's strategy to rely on these industries to stimulate GDP growth. Cong and Ponticelli (2016) also show that new credit was allocated disproportionally more towards state-owned, low productivity firms than to privately-owned, high-productivity firms, reversing the prior trend of efficient reallocation. Using data from 2006-2013, Huang, Pagano, and Panizza (2016) provide evidence that the debt issuance by local governments crowded out investment by private

\footnotetext{
${ }^{21}$ See Bonin and Huang (2001) for how the state dealt with bad loans in the early 2000s; see the State Council (2016) for a recent plan for the Debt-for-Equity Swap.
} 
manufacturing firms. This misallocation reflects the implicit guarantee problem we discussed earlier. As SOEs and local governments have a soft budget constraint, banks are not concerned by their credit risk. The effect of this implicit guarantee is especially large when economic uncertainty is great. Tan, Huang, and Woo (2016) estimate that removing zombie firms, which are mostly insolvent SOEs that are kept alive by bank credit, would lift China's TFP by 1.06 percentage points a year. To the extent that the ability of the Chinese government to resolve any potential debt crisis rests on the country's economic growth, the growth risk is the ultimate risk behind the rising debt problem.

\section{B. Housing Risk}

China has been experiencing a dramatic and long-lasting housing boom across the country since the reform of the housing market in 1990s. This boom has led to a substantial concern in recent years that rising housing prices might have developed into a gigantic housing bubble that might eventually burst and damage both the financial system and the economy, e.g., Wu, Gyourko, and Deng (2016), Glaeser et al. (2017), and Chen and Wen (2017).

An important contributing factor to this concern is the lack of reliable statistics about the housing markets across the country. Fang, Gu, Xiong, and Zhou (2015) provide a useful account of these issues by examining a detailed data set of mortgage loans and constructing housing price indices for 120 major cities in China in 2003-2013 based on sequential sales of new homes within the same housing developments. Their housing price indices show enormous housing price appreciation across China in 2003-2013: an average annual real growth rate of $13.1 \%$ in the four first-tier cities, $10.5 \%$ in second-tier cities, and $7.9 \%$ in third-tier cities. Interestingly, they also show that the enormous price appreciations were accompanied by equally spectacular growth in households' disposable income_-an average annual real growth rate of about $9.0 \%$ throughout the country during the decade. The quickly rising household incomes, together with a well-known observation of high down payment ratios of at least $20 \%$, and typically $40 \%$, on mortgage loans, make the financial risk brought by a potential housing market crash much lower than that faced by the U.S. housing market in the mid-2000s. 
Yet, this study also finds that low-income home buyers often endured enormous financial burdens in buying homes at price-to-income ratios of around eight in second- and third-tier cities and, in some years, even over ten in first-tier cities. ${ }^{22}$ It is difficult to simply attribute the willingness of these households to endure this large financial burden to their consumption needs. Instead, their home purchases are likely driven by a speculative motive to gain from future housing price appreciations. ${ }^{23}$

Households' expectation of high housing price appreciations can be attributed to two key factors. One is a behavioral reason, and the other an institutional reason. First, the human tendency of extrapolating past trends into future trends is likely to cause households to hold high expectations of rapid income growth and housing price appreciations going forward, e.g., Case and Shiller (2003), Gennaioli, Shleifer, and Vishny (2015), Barberis, Greenwood, Jin, and Shleifer (2016). Through such expectations, the housing market risk is also ultimately driven by the economic growth risk. If the Chinese economy can maintain a high growth rate, which has slowed to $6.9 \%$ in recent quarters, the households' high expectations would be sustainable. However, some critics such as Pritchett and Summers (2014) argue that a mean reversion of the spectacular growth rate of the Chinese economy might soon occur. If so, there is a serious risk imposed by the subsequent collapse of household expectations on housing prices.

Second, the government's countercyclical interventions also reinforce home buyers' high expectation of future housing price appreciations. As summarized by Fang, Gu, Xiong, and Zhou (2015), local governments control land supply and heavily rely on land revenue, and banks are heavily exposed to risks in the real estate sector. As a result, it is widely perceived that the real estate sector is too important to fail. Indeed, consistent with this perception, the central government has frequently intervened in the housing market. When the market is considered

\footnotetext{
${ }^{22}$ In concrete terms, this means that a household paid eight times its annual disposable income to buy a home. Suppose that the household made a down payment of $40 \%$ and took a mortgage loan for the other $60 \%$ of the home price, which would be 4.8 times its annual income. A modest mortgage rate of $6 \%$, which is low relative to the actual rate observed during the decade, would require the household to use nearly $30 \%$ of its annual income to pay for the interest on the mortgage loan, in addition to consuming another $16 \%$ of its annual income to pay down the mortgage loan based on a linear schedule for a 30-year loan. Together, buying the home entailed saving 3.2 times the annual household income to make the down payment and another $45 \%$ of its annual income to service the mortgage loan.

${ }^{23}$ See Zhang (2017) for a theoretical model to analyze China's housing price dynamics from households' liquidity constraints and expectations.
} 
overheated, the PBC tends to tighten mortgage down payment requirements and raise mortgage interest rates. When the market is considered depressed, the PBC tends to reverse these measures and even use monetary policy to provide additional supports. These interventions have so far prevented any major crash in the real estate market at the national level.

Overall, the enormous housing price appreciation across China is supported by rapid household income growth, yet the high price-to-income ratios across different cities build on high expectations of future economic growth and income growth. Thus, like the debt crisis risk, the housing risk is also essentially the economic growth risk. If the economic growth rate falls substantially below the currently level of $6.9 \%$ in the near future, it would be difficult to sustain the home buyers' high expectations and thus to keep the price-to-income ratios at the current level.

The real estate boom across China also has an important effect on firm investment and the efficiency of capital allocation across firms. Chen, Liu, Xiong, and Zhou (2017) document an intriguing observation that publicly listed firms in China, excluding financial, real estate, and construction firms, on average spent nearly 20\% of capital investment in 2000-2015 on acquiring land; not just industrial land, but also commercial land and residential land, which cannot be used to build production facilities. In some years land investment contributed to as high as $40 \%$ of these firms' investments. More important, this study finds that the ongoing real estate boom across China not only leads to the well-known collateral effect, through which rising land prices allow land-holding firms to get more bank loans collateralized by their land holdings, but also two additional effects. ${ }^{24}$ One is the so-called crowding out effect, through which the real estate boom crowds out the access of non-land-holding firms to bank financing. ${ }^{25}$ The other is the so-called speculation effect, through which rising land prices induce land-holding firms with access to financing to acquire more land and reduce their non-land investment. ${ }^{26}$ Furthermore, they find that firms with lower, rather than higher, Tobin's Q and productivity tend to hold land.

\footnotetext{
${ }^{24}$ See also Bleck and Liu (2017) for a theoretical analysis on the effect of credit expansion on capital misallocation through collateral value.

25 Similar crowding out effect is also documented by Shi, Wang and Wu (2016).

${ }^{26}$ Shi (2017) also finds that the real estate boom induces capital reallocation within existing private businesses from the manufacturing sector to the real estate sector.
} 
As a result, through these three effects, the real estate boom has a profound, negative impact on the efficiency of capital allocation across firms, thus hurting China's overall economic growth. This growth effect may in turn exacerbate the housing risk.

\section{Capital Outflow Risk}

Figure 5: China's Inward and Outward Direct Investment

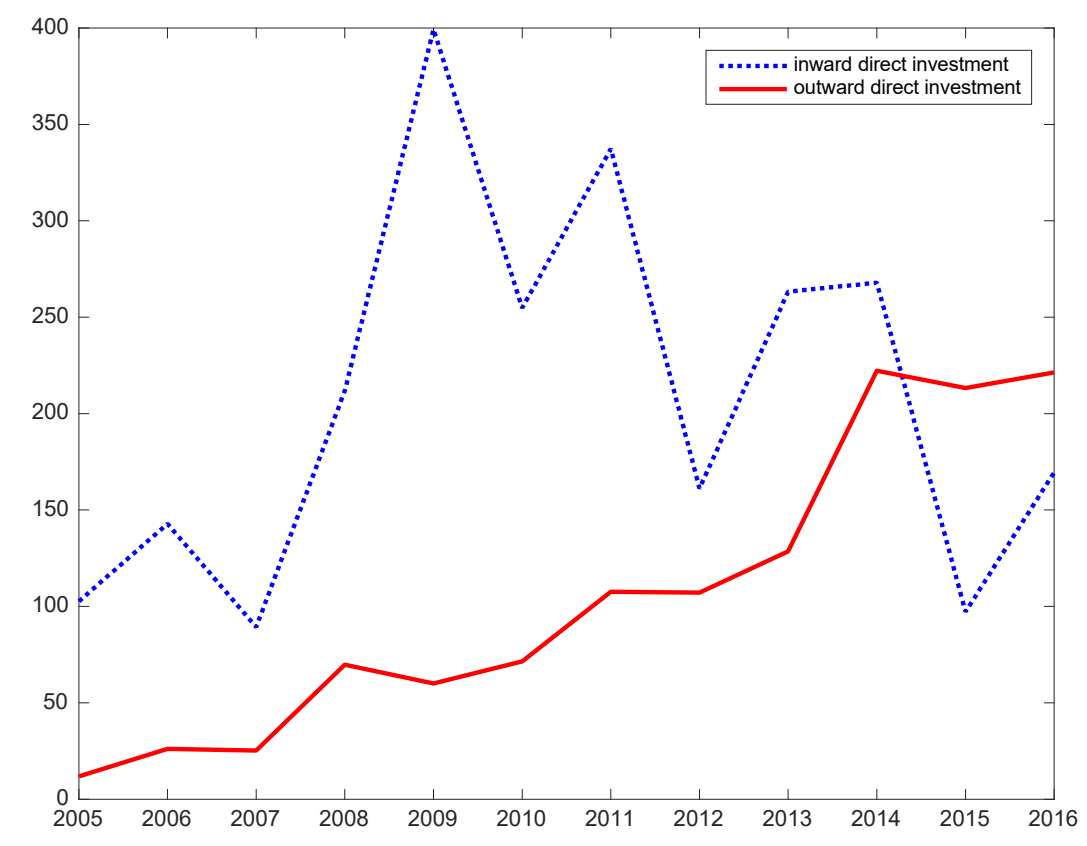

The dotted and solid lines plot China's inward and outward foreign direct investment (billion USD). Data source: State Administration of Foreign Exchange

To modernize its financial system, China has gradually opened up its capital accounts. China is the largest recipient of foreign direct investment among developing economies, with an average of 200 billion USD since 2005 (see the dotted line in Figure 5). China's outward direct investments were small before the mid-2000s but grew very fast afterwards (see the solid line in Figure 5). Controls on international portfolio investments have been partially liberalized, though the inflow and outflow of portfolio investments remain an order of magnitude smaller than direct 
investments. ${ }^{27}$ China also made a great effort to internationalize RMB. In November 2016, it has successfully accomplished a milestone of getting RMB into the IMF's SDR basket, together with the U.S. dollar, the euro, the Japanese yen, and the British pound, with a weight of $10.92 \%$. This SDR membership establishes RMB as a reserve currency. The capital account surplus, together with the current account surplus, led to a rapid growth of foreign reserves, which peaked at a level of 4 trillion U.S. dollars in 2014. See Prasad (2017) for a detailed account of these developments.

The two-decade-long foreign reserve accumulation ended in 2015. Foreign reserves fell by a quarter in one year and are now back to 3 trillion U.S. dollars. This adds to the growing concerns about China's financial stability. Trade surplus is declining, as a consequence of the increase in investment after 2008 (see Figure 3). ${ }^{28}$ Yet, despite the plunge in foreign reserves, China still has a sizable trade surplus, which is about $2 \%$ to $3 \%$ of its GDP. Capital outflow plays a much bigger role. In 2015, for the first time since the economic transition started in the late 1970s, China's outward direct investment exceeded its inward direct investment (see Figure 5). This is not entirely unanticipated. In fact, the inward direct investment has been on a declining trend since 2010, while the opposite is true for outward investment. We want to emphasize two factors that may turn capital inflow to outflow. The deteriorating resource allocative efficiency in the postcrisis period lowered the aggregate return to capital: It dropped from an average above $10 \%$ before 2008 to 4\% in 2013 (Bai and Zhang, 2015). In other words, China has been losing its attraction to foreign capital. In addition, the skyrocketing housing prices greatly increase Chinese households' net worth and provide incentive for them to diversify their portfolios. A back-ofenvelope calculation suggests Chinese households have total wealth of 600 trillion yuan. ${ }^{29}$ Converting merely $3 \%$ of the domestic assets into foreign assets would exhaust entirely China's current foreign reserves. As one can see from Figure 5, the outward direct investment jumped to about 220 billion USD in 2014 and 2015, almost doubling the number from 2013. Although we

\footnotetext{
${ }^{27}$ For instance, foreign investors identified as "qualified foreign institutional investors" (QFIIs) are allowed to buy Chinese stocks and bonds. See Song, Storesletten and Zilibotti (2014) for more institutional details and Chang, Liu and Spiegel (2015) for a theoretical analysis on the tradeoff between sterilization and domestic price stability.

${ }^{28}$ See, e.g., Sun and $\mathrm{Lu}(2012)$ for a structural view of the declining trade surplus.

${ }^{29}$ We estimate financial assets of 90 trillion Yuan by the end of 2015, with household bank deposits of 48.5 trillion and stock market value of 41.8 trillion (assuming all circulated shares are held by Chinese households). Xie and Jin (2015) find that financial assets account for $10.6 \%$ of the total Chinese household wealth in 2012. Assume the proportion of financial assets to be $15 \%$ in 2015 , we obtain the total wealth of 600 trillion Yuan.
} 
do not have the data, anecdotal stories about Chinese real estate buyers around the world suggest that portfolio diversification plays an important role in boosting the outward investment.

The dwindling trade surplus and the reversal of capital flows put depreciation pressure on the Chinese yuan. The sudden but mild depreciation by 2\% in August 2015 failed to defuse the risk. The currency continued to depreciate by $10 \%$ against the USD and by $15 \%$ against a basket of currencies weighted by trade in 2016. The deprecation expectation further fueled capital outflow, which, in turn, led to speculation and strengthened deprecation expectations. To break the vicious cycle, the Chinese government chose to impose stricter capital controls and reserve requirements on onshore RMB deposits of offshore financial institutions in 2016. The latest statistics suggest that these measures have been effective. China's outward direct investment in the first half of 2017 was 53 billion USD, about $40 \%$ of the investment in the first half of 2016 . The exchange rate has also stabilized. Once again, the concern is about the medium- and longrun risks. If resource allocation efficiency continues to worsen, the Chinese government would probably have to depreciate the yuan by a big margin. Moreover, given the heavy interventions by the government in the exchange rate markets, the expectation about how the Chinese government would manage the exchange rate in the future is also important for the market to form depreciation expectations.

\section{Stock Market Risk}

The large volatility in China's stock market also adds to the concerns about the country's financial stability. In particular, the boom and bust of the stock market in 2015 have caused anxiety across the globe about the health of China's financial system. It is useful to note several important characteristics of China's stock market.

First, like other sectors of the financial system, the stock market was initially developed in early 1990s to help fund and improve the ailing SOEs. This mission dictates that the regulations and policy enforcements of the stock market are protective of SOEs, as reflected in various aspects of stock market operations. IPOs in the stock market are subject to an aggregate quota determined by the CSRC, which allocates the quota across regions and industries according to regional 
development goals. During the first 15 years of the stock market, SOEs, enjoyed the privilege of being listed, while private firms were able to get listed only in recent years, e.g., Allen and Shen (2012). This selection makes the listed firms poorer performers than nonlisted firms both ex ante and ex post, and consequently the stock market has offered disappointing returns to investors in its 25-year history despite China's spectacular economic growth, e.g., Allen, Qian, Shan, and $\mathrm{Zhu}$ (2017). There is also extensive evidence showing that political connections affect IPO selection and IPO returns, e.g., Fan, Wong, and Zhang (2007), Piotroski and Zhang (2014).

China has adopted accounting regulations and standards for publicly listed firms similar to most developed countries, and, in particular, strict profit requirements for firms to qualify for IPOs. However, the enforcement of the accounting rules has been lax and penalties for accounting violations have been light. See Piotroski and Wong (2012) and Allen and Shen (2012) for detailed accounts of the information environment and legal enforcement related to publicly listed firms in China. Strict enforcement would have disqualified some SOEs for IPOs as they relied on earnings management to satisfy the IPO requirement on IPOs, e.g., Aharony, Lee, and Wong (2000), Chen, and Yuan (2004), Chen, Lee, and Li (2008), Allen, Qian, Shan, and Zhu (2017). Furthermore, there have been very few delistings in China's stock market, in sharp contrast to the large number of delistings in the U.S. stock market, which are roughly in balance with the number of IPOs each year. One can again explain the small number of delistings based on the soft budget constraint or the political power of the SOEs, which can often resist orders from the CSRC. The lack of delistings in turn limits the number of new IPOs to the stock market and leads to substantial shell value of weak listed firms that wait for merger offers from unlisted firms seeking for an alternative channel to be listed, e.g., Lee, Qu, and Shen (2017).

Second, China's stock market was developed outside the banking system, as banks are not allowed to directly trade in the stock exchanges. As a result, the stock market has been populated by retail investors, who only started to invest in stocks in early 1990s after the stock market was shut down for nearly half a century. A large body of academic studies has shown that the Chinese stock market is substantially more speculative than the U.S. market. See Carpenter and Whitelaw (2017) for a review. Stock prices in China's A-share market are highly volatile, as demonstrated by the dramatic boom and bust of stock prices in 2007-2008 and again in 2014 
2015 (see Figure 6). The A-share market also has a remarkably high turnover rate, which often rose to a monthly rate of $100 \%$ and had routinely stayed at the level of $40 \%$ per month-the highest among major national stock markets. The turnover rate directly reflects the speculative behavior of many investors, who aim to make a quick profit through trading rather than investing for the long term. There is also extensive evidence linking investors' speculative motives, induced by their heterogeneous beliefs, to stock prices in China, e.g., Mei, Scheinkman, and Xiong (2009), Andrade, Bian, and Burch (2013), Chang, et al. (2015), Hong et al. (2014), Jia, Wang, and Xiong (2017). The spectacular price bubble associated with the deep out-of-themoney put warrants traded on the Shanghai and Shenzhen Stock Exchanges in 2005-2008 provided another vivid example of how investors who lacked the basic knowledge of stock warrants caused frenzied speculation and highly inflated prices for fundamentally worthless securities, e.g., Xiong and Yu (2011), Gong, Pan, and Shi (2016), Pearson, Yang, and Zhang (2017).

Figure 6: Shanghai Stock Exchange Composite Index and Monthly Market Turnover Rate

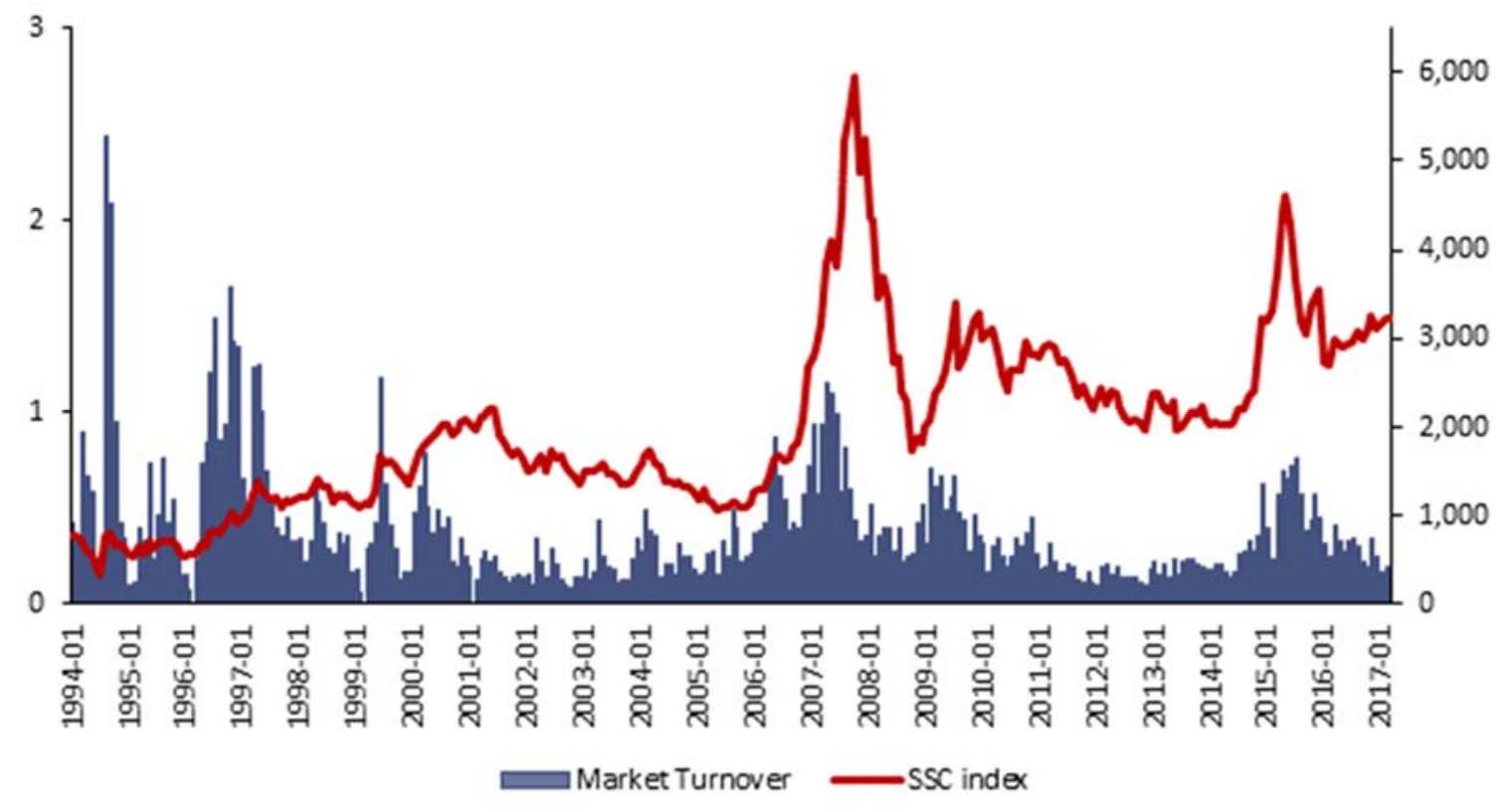

Note: The Shanghai Stock Exchange Composite Index uses the right y-axis, while the monthly market turnover rate uses the left y-axis. 
Third, despite the rapid growth of China's stock market, equity offering contributed to only about $5 \%$ of the total social financing to the real economy in 2015, while bank loans contributed over 70\% (Social Financing Statistics provided by NBS). Due to this relatively small contribution to the social financing, the high stock market volatility is usually not a serious concern to the real economy.

Finally, the boom and bust of the stock market in 2015 deserves special attention due to the heavy use of financial leverage by stock investors. China has allowed investors to buy stocks on margin only since March 2010, initially within a highly restricted list of only 90 stocks. The list was gradually expanded to cover 800 stocks by September 2014. While buying on margin in the stock exchanges was closely monitored, a large amount of leverage was also employed outside the exchange system. Allegedly, some investors used leverage of a multiple of 8 or even 10 to buy stocks in the off-exchange margin system. This large amount of leverage served as a strong propeller of the stock market before it peaked in June 2015. As the market started to turn back down, leverage caused a liquidity spiral, as often seen in financial market crashes across the world, leading to forced and preemptive liquidation by the investors with large leverage, e.g., Bian, Da, Lou, and Zhou (2017) and Bian, He, Shue, and Zhou (2017). At one point, this liquidity spiral threatened the stability of the financial system, and the CSRC had to orchestrate a national team of financial firms to bail out the falling stock market. The bailout eventually calmed down the stock market in late summer of 2015 (see Huang, Miao, and Wang, 2016).

In the aftermath of the dramatic stock market boom and bust, the CSRC has substantially tightened the use of margin buying both on and off the two stock exchanges. It is thus unlikely for similar leverage induced cycles to occur again in China's stock market in the near future.

\section{E. Policy Risk}

Due to the two-track structure of the Chinese economy, the government has maintained a highly active role in managing the economy and the financial system. The extensive policy interventions by the government have important implications about the risk and efficiency of the financial system. 
There are several key reasons that motivate government interventions in the financial system. First, as we discussed before, the financial system provides the necessary financial instruments to fund the government's policy agenda. As a result, the government has taken various initiatives to develop different financial markets/sectors to meet its funding needs. Second, the government believes that countercyclical management of the financial system is necessary due to the presence of a large pool of inexperienced institutions and investors, which are often subject to excessive sentimental fluctuations. Guided by a paternalistic philosophy to protect inexperienced investors and maintain market stability, the government has employed a wide range of policy tools to intervene in the financial system.

For example, the PBC has frequently used its authority to change benchmark interest rates for bank deposits and loans, which directly affect the costs of funding throughout the whole economy. The PBC has also frequently changed the required reserve ratio for banks to manage liquidity in the banking system. In recent years, the PBC has also developed a macroprudential framework, which allows the PBC to manage the risk-taking of banks and other financial institutions by varying the required capital for their different investment activities. See Sun (2015) for a thorough account of the PBC's financial and monetary policies. As discussed earlier, the government has also used a range of policy tools to manage cycles in the real estate sector, including changing interest rates and down payment requirements in mortgage loans, imposing restrictions on second-home purchases by residents and investment home purchases by nonresidents, e.g., Fang, Gu, Xiong, and Zhou (2015). In the stock market, the CSRC has also used several policy tools to manage stock market fluctuations. The CSRC directly controls IPO issuance and has suspended IPO issuance 9 times since 1992, sometimes for longer than one year. ${ }^{30}$ Even during regular periods, the CSRC determines the aggregate quota for IPO issuance and the allocation of the IPO quota across sectors and regions. The CSRC has also changed the stamp duties imposed on stock trading for 7 times since 1992, with the tax rate going up to as high as 1\% in 1998 and coming down to as low as $0.1 \%$ in recent years, e.g., Deng, Liu, and Wei (2017).

\footnotetext{
${ }^{30}$ Cong, Howell, and Zhang (2017) find that the disruptions to the IPO process had strong negative effects on firms' innovation activities, such as patent applications and fixed tangible investments.
} 
Active government interventions have profound impacts on the financial system. Policies and regulations can deliver unintended consequences, some of which may be entirely counterproductive. ${ }^{31}$ While countercyclical interventions help to stabilize financial markets, they may reduce the information efficiency of asset prices. An unintended consequence of government interventions is that interventions add another source of noise from the government's policymaking processes into the financial markets. When the interventions are sufficiently active, this government noise factor would become a key factor in driving market dynamics. When this happens, investors and market participants may devote their limited attention to analyzing the government factor rather than economic fundamentals, which in turn may make asset prices in the financial system less efficient in reflecting economic fundamentals. Brunnermeier, Sockin, and Xiong (2017b) recently developed a theoretical model to highlight this economic mechanism.

We may also view the relationship between the government and financial markets through a perhaps inappropriate metaphor. Parents' meticulous caring for children may serve to indulge the children's misbehavior rather than make them more responsible for their own behavior. Similarly, active government interventions may indulge investors' speculative behavior in financial markets rather than make them more responsible for their own investment behavior. That is, market participants may engage in speculation about future changes and errors in the government policies.

Brunnermeier, Sockin, and Xiong (2017a) further argue that this unintended consequence of government interventions may undermine the government's financial reform. "Crossing the river by touching the stones" has been a hallmark strategy of China's economic reform. This strategy has worked well because it usually takes months, even quarters, for the economy to react to a policy change, leaving policy makers just enough time to study the reaction and discern appropriate policy adjustments. However, predictable policy changes in financial markets would stimulate speculation by market participants. Speculation, especially frenzied speculation with high leverage, may destabilize the markets. When this happens, speculation may cause asset

\footnotetext{
${ }^{31}$ Hachem and Song (2017) show that tightening of liquidity rule may lead to credit boom through shadow banking.
} 
prices to overshoot to levels beyond what are justified by the government's intended policy change and may even force the government to make the policy change more aggressive than initially planned. At a deeper level, this leads to the widely discussed time-inconsistency problem in policy making.

Indeed, in China's stock market, Chen at al. (2017) provide empirical evidence to show that investor speculation can make the $10 \%$ daily price limit rule - a widely regarded market stabilization mechanism - counter-productive. Specifically, they find that large investors tend to push stock prices up to the $10 \%$ limit on days with large positive returns and then profit from selling on the next day. In doing so, their trading makes extreme positive returns more, rather than, less likely. Furthermore, Liu, Xu, and Zhong (2017) find that such trading restrictions served to spread market contagion during China's stock market crash in the summer of 2015, again due to investors' preemptive and speculative behavior. In China's short-lived warrant market, Cai et al. (2017) provide another example that the government's increase in the stamp tax for stock trading in May 2007 at the height of a stock market boom led the trading frenzy to migrate from the stock market to the warrant market, which was not subject to the stamp tax. Furthermore, Chen, Petukhov, and Wang (2017) develop a theoretical model to show that market-wide trading halts may increase, rather than decrease, the probability of hitting the triggering price threshold, which helps explain the short-lived circuit breakers adopted by China's stock market in January 2016.

Frequent government interventions also reinforce the perceived government guarantees by market participants, which in turn create another channel to indulge excessive risk taking by market participants. See Zhu (2016) for a full account of how government guarantees have led to widespread risk-taking behavior across China.

Through the aforementioned channels, households and firms across the country have strong incentives to use various instruments offered by the financial system to load on risks that are tied to policy agendas and regulations of the government. As a result, the financial system may serve to aggregate risks - risks that are backed by the government, instead of spreading risks across 
different households and firms. This may eventually reduce the efficiency of the financial system and exacerbate the systemic risk.

\section{References}

Acharya, V., Qian, J., and Yang, Z. (2016). In the Shadow of Banks: Wealth Management Products and Issuing Banks' Risk in China. Working Paper.

Aharony, J., Lee, C.W.J, and Wong, T. J. (2000). Financial Packaging of IPO Firms in China. Journal of Accounting Research, 38(1), 103-126.

Allen, F. and Qian, J. (2014). China's Financial System and the Law. Cornell International Law Journal, 47(3), 499-554.

Allen, F., Qian, J., and Gu, X. (2017). An Overview of China's Financial System. Annual Review of Financial Economics, 9(1), 191-231.

Allen, F., Qian, J., and Qian, M. (2005). Law, Finance, and Economic Growth in China. Journal of Financial Economics, 77(1), 57-116.

Allen, F., Qian, J., Shan, C., and Zhu, L. (2017). Dissecting the Long-Term Performance of the Chinese Stock Market. Working Paper, Imp. Coll. London.

Allen, F., Qian, J., Zhang, C., Zhao, M. (2012). China's Financial System: Opportunities and Challenges. In Capitalizing China, ed. J Fan, R Morck, pp. 63-148. Chicago: Univ. of Chicago Press.

Allen, F., Qian, Y., Tu, G., and Yu, F. (2016). Entrusted Loans: A Close Look at China's Shadow Banking System. Working Paper.

Allen, W.T. and Shen, H. (2012). Assessing China's Top-Down Securities Markets. In Capitalizing China, ed. J Fan, R Morck, pp. 149-195. Chicago: Univ. of Chicago Press.

Andrade, S.C., Bian, J., and Burch, T.R. (2013). Analyst Coverage, Information, and Bubbles. Journal of Financial and Quantitative Analysis, 48(5), 1573-1605.

Bai, C.E., Hsieh, C.T., and Song, Z. (2016). The Long Shadow of China's Fiscal Expansion. Brookings Papers on Economic Activity, 129-165.

Bai, C.E., Hsieh, C.T., and Song, Z (in progress), Institutional Foundations for China's Growth and Slowdown. 
Bai, C.E. and Zhang, Q. (2015). The Return on Capital in China and Its Determinants. China Economists, 10(3), 20-37.

Barberis, N., Greenwood, R., Jin, L., and Shleifer, A. (2016). Extrapolation and Bubbles (No. w21944). National Bureau of Economic Research.

Bian, J., Da, Z., Lou, D., and Zhou, H. (2017). Leverage Network and Market Contagion. Working Paper, Univ. of Notre Dame.

Bian, J., He, Z., Shue, K., and Zhou, H. (2017). Leverage-Induced Fire Sales and Stock Market Crashes. Working Paper, Univ. of Chicago.

Bleck, A. and Lu, X. (2017). Credit Expansion and Credit Misallocation. Journal of Monetary Economics, Forthcoming.

Bonin, J.P. and Huang, Y. (2001). Dealing with the Bad Loans of the Chinese Banks. Journal of Asian Economics, 12(2), 197-214.

Borst, N. and Lardy, N. (2015). Maintaining Financial Stability in the People's Republic of China during Financial Liberalization. Peterson Institute for International Economics Working Paper No. 15-4.

Brandt, L., Van Biesebroeck, J., and Zhang, Y. (2012). Creative Accounting or Creative Destruction? Firm-Level Productivity Growth in Chinese Manufacturing. Journal of Development Economics, 97(2), 339-351.

Brandt, L., Wang, L. and Zhang, Y. (2017). Productivity in Chinese Industry: 1998-2013. Working Paper, University of Toronto.

Brandt, L. and X. Zhu. (2000). Redistribution in a Decentralized Economy: Growth and Inflation in China under Reform, Journal of Political Economy, 108(2), 422-439.

Brunnermeier, M., Sockin, M., and Xiong, W. (2017a). China's Gradualistic Economic Approach and Financial Markets. American Economic Review Papers \& Proceedings, 107(5), 608-13.

Brunnermeier, M., Sockin, M., and Xiong, W. (2017b). China's Model of Managing the Financial System. Working Paper, Princeton Univ.

Cai, J., He, J., Jiang, W., and Xiong, W. (2017). The Whack-A-Mole Game: Tobin Tax and Trading Frenzy. Working Paper, Princeton Univ.

Carpenter, J.N. and Whitelaw, R.F. (2017). The Development of China's Stock Market and Stakes for the Global Economy. Annual Review of Financial Economics, 9(1), 233-57. 
Case, K. E. and Shiller, R. J. (2003). Is There a Bubble in the Housing Market? Brookings Papers on Economic Activity, 2003(2), 299-342.

Chang, C., Z. Liu and M.M. Spiegel. (2015). Capital Controls and Optimal Chinese Monetary Policy, Journal of Monetary Economics, 74, 1-15.

Chang, Y.C., Hong, H.G., Tiedens, L., Wang, N., and Zhao, B. (2015). Does Diversity Lead to Diverse Opinions? Evidence from Languages and Stock Markets. Working Paper, Columbia Univ.

Chen, J. and Chen, Z. (2016). Confucianism, Social Norms and Household Savings Rates in China. Working Paper, Yale University.

Chen, H., Petukhov, A., Wang, J. (2017). The Dark Side of Circuit Breakers. Working Paper, MIT.

Chen, K., Ren, J., and Zha, T. (2016). What We Learn from China's Rising Shadow Banking: Exploring the Nexus of Monetary Tightening and Banks' Role in Entrusted Lending. Working Paper, Emory University.

Chen, K., Higgins, P., Waggoner, D., and Zha, T. (2017). Impacts of Monetary Stimulus on Credit Allocation and Macroeconomy: Evidence from China. Working Paper, Emory University.

Chen, K. and Wen, Y. (2017). The Great Housing Boom of China. American Economic Journal: Macroeconomics, 9 (2), 73-114.

Chen, K.C.W. and Yuan, H. (2004). Earnings Management and Capital Resource Allocation: Evidence from China's Accounting-Based Regulation of Rights Issues. The Accounting Review, 79(3), 645-665.

Chen, T., Gao, Z., He, J., Jiang, W., and Xiong, W. (2017). Daily Price Limits and Destructive Market Behavior. Journal of Econometrics. Forthcoming

Chen, T., Liu, L., Xiong, W., and Zhou, L.A. (2017). Real Estate Boom and Misallocation of Capital in China, Working Paper, Princeton University.

Chen, X., Lee, C.J., and Li, J. (2008). Government Assisted Earnings Management in China. Journal of Accounting and Public Policy, 27(3), 262-274.

Chen, Z., He, Z., and Liu, C. (2017). The Financing of Local Government in China: Stimulus Loan Wanes and Shadow Banking Waxes. NBER Working Paper, No. w23598.

Chen, Z. (2015). China's Dangerous Debt. Foreign Affairs, 94, 13-24. 
Chivakul, M. and Lam, R.W. (2015). Assessing China's Corporate Sector Vulnerabilities. IMF Working Paper.

Choukhmane, T., Coeurdacier, N., and Jin, K. (2016). The One-Child Policy and Household Savings. Working Paper.

Cong, L. W., Howell, S., and Zhang, R. (2017). The Impact of Delay in Going Public: Evidence from China. Working Paper, University of Chicago.

Cong, L.W. and Ponticelli, J. (2016). Credit Allocation Under Economic Stimulus: Evidence from China.

Cooper, R. and Zhu, G. (2017), Household Finance in China, NBER Working Paper No.23741.

Deng, Y., Liu, X., and Wei, S. (2017). One Fundamental and Two Taxes: When Does a Tobin Tax Reduce Financial Price Volatility? Journal of Financial Economics. Forthcoming Dewatripont, M. and Maskin, E. (1995). Credit and Efficiency in Centralized and Decentralized Economies. The Review of Economic Studies, 62(4), 541-555.

Diamond, D.W. and Dybvig, P.H. (1983). Bank Runs, Deposit Insurance, and Liquidity. Journal of Political Economy, 91(3), 401-419.

Du, J., Li, C., and Wang, Y. (2016). Shadow Banking Activities in Non-Financial Firms: Evidence from China. Working Paper.

Fan, J.P.H., Wong, T.J., and Zhang, T. (2007). Politically Connected CEOs, Corporate Governance, and Post-IPO Performance of China's Newly Partially Privatized Firms. Journal of Financial Economics, 84(2), 330-357.

Fang, H., Gu, Q., Xiong, W., and Zhou, L. (2015). Demystifying the Chinese Housing Boom. NBER Macroeconomics Annual, 30(1), 105-166.

Gennaioli, N., Shleifer, A., and Vishny, R. (2015). Neglected Risks: The Psychology of Financial Crises. The American Economic Review, 105(5), 310-314.

Glaeser, E., Huang, W., Ma, Y., and Shleifer, A. (2017). A Real Estate Boom with Chinese Characteristics. The Journal of Economic Perspectives, 31(1), 93-116.

Ge, F., Luo, J., Song, Z. and Yuan, Y. (2017). Aggregating Misallocation under Endogenous Markups, Theory and Evidence from China. Working Paper.

Gong, B., Pan, D., and Shi, D. (2016). New Investors and Bubbles: An Analysis of the Baosteel Call Warrant Bubble. Management Science, 63(8), 2493-2508. 
Gordon, R.H. and Li, W. (2003). Government as a Discriminating Monopolist in the Financial Market: The Case of China. Journal of Public Economics, 87(2), 283-312.

Hachem, K. (2017). Shadow Banking in China (prepared for the same issue in Annual Review of Financial Economics).

Hachem, K. and Song, Z.M. (2016). Liquidity Regulation and Unintended Financial Transformation in China. Working Paper.

Hachem, K. and Song, Z.M. (2017). Liquidity Rules and Credit Booms. Working Paper.

He, Z. and Xiong, W. (2012). Dynamic Debt Runs. The Review of Financial Studies, 25(6), 1799-1843.

Hong, H., Jiang, W., Wang, N., and Zhao, B. (2014). Trading for Status. The Review of Financial Studies, 27(11), 3171-3212.

Hsieh, C.T. and Klenow, P.J. (2009). Misallocation and Manufacturing TFP in China and India. The Quarterly Journal of Economics, 124(4), 1403-1448.

Hsieh, C.T. and Song, Z. (2015). Grasp the Large, Let Go of the Small: The Transformation of the State Sector in China. Brookings Papers on Economic Activity, 295-366.

Wang, Y. (2008). Capitalism with Chinese Characteristics, Cambridge University Press.

Huang, Y., Miao, J., and Wang, P. (2016). Saving China's Stock Market. Working Paper, Boston Univ.

Huang, Y., Pagano, M., and Panizza, U. (2016). Public Debt and Private Firm Funding: Evidence from Chinese Cities.

Jia, C., Wang, Y., and Xiong, W. (2017). Market Segmentation and Differential Reactions of Local and Foreign Investors to Analyst Recommendations. The Review of Financial Studies, 30(9), 2972-3008.

Kornai, J. (1979). Resource-Constrained Versus Demand-Constrained Systems. Econometrica, 47(4), 801-819.

Kornai, J. (1980). Economics of Shortage. Amsterdam: North-Holland.

Kornai, J., Maskin, E., and Roland, G. (2003). Understanding the Soft Budget Constraint. Journal of Economic Literature, 41(4), 1095-1136.

Lau, L.J., Qian, Y., and Roland, G. (2000). Reform Without Losers: An Interpretation of China's Dual-Track Approach to Transition. Journal of Political Economy, 108(1), 120-143. 
Lee, C., Qu, Y., and Shen, T. (2017). Reverse Mergers, Shell Value, and Regulation Risk in Chinese Equity Markets. Working Paper, Stanford Univ.

Li, D. D. (2001). Beating the Trap of Financial Repression in China. Cato Journal, 21(1), 77-91.

Li, B. and Liu Q. (2017). On the Choice of Monetary Policy Rules for China: A Bayesian DSGE Approach, China Economic Review, 44, 166-185.

Li, H., and Zhou, L. A. (2005). Political Turnover and Economic Performance: The Incentive Role of Personnel Control in China. Journal of Public Economics, 89(9), 1743-1762.Li, X., Liu, X., and Wang, Y. (2014). A Model of China's State Capitalism. Working Paper.

Lin, J.Y., Cai, F., and Li, Z. (1998). Competition, Policy Burdens, and State-Owned Enterprise Reform. The American Economic Review, 88(2), 422-427.

Liu, Zheng, Pengfei Wang, Zhiwei Xu. (2017). Interest-Rate Liberalization and Capital Misallocation, Federal Reserve Bank of San Francisco Working Paper 2017-15.

Liu, X., Xu, J., and Zhong, N. (2017). Trading Restriction as a Channel of Financial ContagionEvidence from China's Stock Market. Working Paper, Peking Univ.

Maliszewski, W., Arslanalp, M.S., Caparusso, J., Garrido, J., Guo, M.S., Kang, J.S., Lam, W.R., Law, D. and Liao, W. (2016). Resolving China's Corporate Debt Problem. International Monetary Fund.

Mei, J., Scheinkman, J., and Xiong, W. (2009). Speculative Trading and Stock Prices: Evidence from Chinese AB Share Premia. Annals of Economics and Finance, 10(2), 225-255.

Mian, A. and Sufi, A. (2009). The Consequences of Mortgage Credit Expansion: Evidence from the US Mortgage Default Crisis. The Quarterly Journal of Economics, 124(4), 1449-1496.

Morris, S., and Shin, H. S. (2004). Coordination Risk and the Price of Debt. European Economic Review, 48(1), 133-153.

Myers, S.C. (1977). Determinants of Corporate Borrowing. Journal of Financial Economics, 5(2), 147-175.

Pearson, N., Yang, Z., and Zhang, Q. (2017). Evidence about Bubble Mechanisms: Precipitating Event, Feedback Trading, and Social Contagion. Working Paper, Univ. Illinois UrbanaChampaign.

Piotroski, J.D. and Wong, T.J. (2012). Institutions and Information Environment of Chinese Listed Firms. In Capitalizing China, ed. J Fan, R Morck, pp. 201-242. Chicago: Univ. of Chicago Press. 
Piotroski, J.D. and Zhang, T. (2014). Politicians and the IPO Decision: The Impact of Impending Political Promotions on IPO Activity in China. Journal of Financial Economics, 111(1), 111-136.

Prasad, E. (2017). Gaining Currency: The Rise of the Renminbi. Oxford University Press.

Pritchett, L. and Summers, L.H. (2014). Asiaphoria Meets Regression to the Mean.

Qian, Y. and Roland, G. (1998). Federalism and the Soft Budget Constraint. The American Economic Review, 88(5), 1143-1162.

Shi, J., Wang, Y. and Wu., W. (2016). The Crowding-out Effect of Real Estate Markets on Corporate Innovation: Evidence from China. Working Paper.

Shi, Y. (2017). Real Estate Booms and Endogenous Productivity Growth, Working Paper, MIT.

Song, Z., Storesletten, K., and Zilibotti, F. (2011). Growing Like China. The American Economic Review, 101(1), 196-233.

Song, Z., Storesletten, K., and Zilibotti, F. (2014). Growing (with Capital Controls) Like China. IMF Economic Review, 62(3), 327-370.

Song, Z. and Wu, G.L. (2015). Identifying Capital Misallocation. Working Paper.

Sun, G. (2015). Reforms in China’s Monetary Policy. Palgrave Macmillan.

Sun, G. and Jia, J. (2015), Defining China's Shadow Banking and Assessing its Scale: Seen in Terms of the Creation of Credit Money, China's Social Science (in Chinese), 239(11), 92110.

Sun, G. and Lu, D. (2012). Predictive Analysis on Mid-Long Term Trend of Current Account Surplus in China Based on a Perspective of Saving-Investment Structural Change. PBC Working Paper (Chinese version published in Comparative Studies, 63(6), 142-159).

Tan, Y., Huang, Y., and Woo, W.T. (2016). Zombie Firms and the Crowding-Out of Private Investment in China. Asian Economic Papers, 15(3), 32-55.

The State Council of the People's Republic of China. (2016). China Details Plan for Debt-forEquity Swaps. http://english.gov.cn/policies/policy_watch/2016/10/11/content_281475463445096.htm

Walter, C. and Howie, F. (2012). Red Capitalism: The Fragile Financial Foundation of China's Extraordinary Rise. John Wiley \& Sons.

Wang, H., Wang, H., Wang, L., and Zhou, H. (2012). Shadow Banking: China's Dual-Track Interest Rate Liberalization, Working paper, Tsinghua University. 
Wang, Y. (2016). Is China's Rapid Growth Sustainable? A Theory of Politico-Economic Transition and State Capitalism, Working Paper, University of Oslo.

Wei, S.J. and Zhang, X. (2011). The Competitive Saving Motive: Evidence from Rising Sex Ratios and Savings Rates in China. Journal of Political Economy, 119(3), 511-564.

Wong, S.M.L. (2006). China's Stock Market: A Marriage of Capitalism and Socialism. Cato Journal, 26(3), 389-424.

Wu, J., Gyourko, J., and Deng, Y. (2012). Evaluating Conditions in Major Chinese Housing Markets. Regional Science and Urban Economics, 42(3), 531-543.

Wu, J., Gyourko, J., and Deng, Y. (2016). Evaluating the Risk of Chinese Housing Markets: What We Know and What We Need to Know. China Economic Review, 39, 91-114.

Xie, Y. and Jin, Y. (2015). Household Wealth in China. Chinese Sociological Review, 47(3), 203-229.

Xiong, W. and Yu, J. (2011). The Chinese Warrants Bubble. The American Economic Review, 101(6), 2723-2753.

$\mathrm{Xu}, \mathrm{C}$. (2011). The Fundamental Institutions of China's Reforms and Development. Journal of Economic Literature, 49(4), 1076-1151.

Yang, D.T. (2012). Aggregate Savings and External Imbalances in China. The Journal of Economic Perspectives, 26(4), 125-146.

Yang, D.T., Zhang, J., and Zhou, S. (2011). Why Are Saving Rates So High in China? Capitalizing China, edited by Joseph Fan and Randall Morck. Chicago: The National Bureau of Economic Research (NBER), University of Chicago Press: 249-278.

Zhang, Y. (2017). Liquidity Constraints, Transition Dynamics, and the Chinese Housing Return Premium. Working Paper, Peking University.

Zhou, L. A. (2002). Career Concerns, Incentive Contracts, and Contract Renegotiation in the Chinese Political Economy. Stanford University.

Zhou, L. A. (2007). Governing China's Local Officials: An Analysis of Promotion Tournament Model (Zhongguo difang guanyuan de jingsheng jinbiaosai moshi yanjiu). Economic Research Journal (Jingji yanjiu), 42(7), 36-50. Zhou, X. (2006). China’s Corporate Bond Market Development: Lessons Learned, BIS Paper No 26.

Zhu, N. (2016). China's Guaranteed Bubble: How Implicit Government Support Has Propelled China's Economy While Creating Systemic Risk. New York, NY: McGraw-Hill Education. 
Zhu, X. (2012). Understanding China's Growth: Past, Present, and Future. The Journal of Economic Perspectives, 26(4), 103-124.

Zhu, X. (2017). The Varying Shadow of China's Banking System. Working Paper.

Zilibotti, F. (2017). Growing and Slowing Down Like China. Journal of the European Economic Association, 15(5), 943-988. 